\title{
Human Trafficking: \\ Canadian Government Policy and Practice
}

\author{
Jacqueline Oxman-Martinez, Andrea Martinez, and Jill Hanley
}

\begin{abstract}
A recent study undertaken by the authors (OxmanMartinez and Martinez 200o) examined the Canadian government's response to the traffic of human beings. Information from twenty-one government and NGO informants and a thorough review of state agency policies and international conventions revealed that trafficking and refugee movements have many links. The question raised by the Metropolis Project-Is clandestine entry to Canada a crime or a new form of migration? - is important, given that trafficking may be the only option available to legitimate refugees waiting to escape dangerous or oppressive situations.

Rather than seeking to ease the migration of refugees or addressing the structural causes of trafficking or its social implications, however, Canada's response is focused on the prevention of "irregular movements" (through immigration and border control) and prosecution of the few traffickers successfully apprehended. Preliminary evidence suggests that border control will fail to adequately address the exploitation of women, children, and men-often refugees-within our frontiers. The temporarily defunct Bill c31 (with its measures to control the borders and restrict immigration) threatens the rights of refugees while doing little to prevent human trafficking, protect its victims, or prosecute those who profit from trafficking.
\end{abstract}

\section{Résumé}

Une étude récente faite par les auteurs (Oxman-Martinez et Martinez 200o) s'est penchée sur la réaction du gouvernement canadien au trafic de personnes. Des informations reçues de 21 informateurs se trouvant au gouvernement et dans des ONG, ainsi qu'un réexamen en profondeur des politiques suivies par les agences gouvernementales et des conventions internationales ont révélé qu'il existait des liens multiples entre le flot de réfugiés et le trafic de personnes. La question posée par le Projet Metropolis, c.à-d. "L'entrée clandestine au Canada est-elle un crime ou une nouvelle forme de migration? » est importante, étant donné que le trafic est possiblement l'une des seules options dont disposent les réfugiés légitimes désirant fuir des situations dangereuses ou abusives.

Cependant, au lieu d'essayer d'atténuer le flot de réfugiés ou de s'attaquer aux causes structurelles du trafic ou à ses implications sociales, la réaction du Canada est consacrée à empêcher les "déplacements irréguliers " (contrôle de l'immigration et contrôle aux frontières), et la poursuite en justice des rares trafiquants qu'on arrive à appréhender.

Des indications préliminaires suggèrent que le contrôle aux frontières ne parviendra pas à s'attaquer de façon satisfaisante au problème que constitue l'exploitation, à l'intérieur même de nos frontières, de femmes, d'enfants et d'hommes qui sont souvent des réfugiés. Le projet de loi C-31temporairement défunt — avec ses mesures pour contrôler nos frontières et limiter l'immigration, menace les droits des réfugiés, sans pour autant faire beaucoup pour empêcher le trafic humain, protéger ses victimes ou traduire en justice ceux qui en profitent. 


\section{Introduction}

7 his article presents the findings of a study completed as part of the Trafficking in Human Beings project, an initiative of the Global Challenges and Opportunities Network (GCON)'s Working Group on Transnational Crime. ${ }^{1}$ The goal of the research was to document the nature of human trafficking in Canada and explore the policy issues currently facing federal agencies working in this domain. Hoping to overcome the fragmented and anecdotal nature of most information on human trafficking in Canada, ${ }^{2}$ the authors used interviews, questionnaires, official documents, and a review of the literature to explore the efficacy of the government's response to this phenomenon.

The results of this study reveal that the victims of trafficking are often individuals who might be considered refugees but who are unable to enter the country along conventional paths. For refugees unable to secure official identity or travel documents ${ }^{3}$ or for those who might have difficulty qualifying for refugee status, ${ }^{4}$ smuggling may be the only option to migrate. Unfortunately, individuals who must rely on smuggling to migrate become vulnerable to being trafficked.

Specific government mandates on human trafficking are rare, however, and agency responses to this phenomenon lack coordination. Rather than addressing the structural causes of trafficking or its social implications, Canada's response is focused on the prevention of "irregular movements" (border control) and prosecution of the few traffickers who are actually apprehended. Current approaches to preventing trafficking, protecting its victims, and prosecuting its perpetrators are inadequate. This article will argue that a punitive border control approach, as proposed in the temporarily defunct Bill c-31, threatens the human rights of legitimate refugees and migrants (CCPCYA 2000; Canadian Council for Refugees 2000). Instead, the authors argue for a socio-structural approach for addressing the human rights violations inherent to the traffic of human beings.

\section{Defining Human Trafficking}

One reason for the difficulty in preventing human trafficking and protecting its victims is that the international community has yet to come to a consensus on a definition of the phenomenon. In December 2000, the United Nations is adopted a Protocol to Prevent, Suppress and Punish Trafficking in Persons, Especially Women and Children. This supplemental protocol to the UN Convention against Transnational Organized Crime operates with the following definition:
Trafficking in persons shall mean the recruitment, transportation, transfer, harbouring or receipt of persons, by the threat or use of force, by abduction, fraud, deception, coercion or the abuse of power or by the giving or receiving of payments or benefits to achieve the consent of a person having control over another person, for the purpose of ... sexual exploitation, forced labour or services, slavery or practices similar to slavery. ${ }^{5}$

The authors' research also raised definitional problems among Canadian government agencies, and they argue for further provisions in defining human trafficking. First of all, although the protocol does not mention borders, for the purposes of this research on the Canadian context, trafficking is defined as involving the movement of trafficked individuals across international frontiers. Although there are reasonable arguments for including intranational displacement and forced labour, ${ }^{6}$ we would like to stress the connections of human trafficking to trade globalization and transnational organized crime.

Second, the concept of "consent" is irrelevant to defining human trafficking. Some government officials stated in interviews that they took into consideration whether or not individuals gave their consent to their exploitive situation when deciding if a situation constituted human trafficking. As already mentioned, many individuals choose to be smuggled across borders (implying initial consent), but they may have been unaware that they would later become trafficked and that their freedom would be restricted upon their entry to Canada. Also, trafficked individuals may enter Canada on legal visas (implying initial consent) but find themselves "trafficked" upon arrival. Women who come to Canada as mail-order brides (on a fiancée visa), as domestic workers (live-in care giver visa), or as "entertainers" (work visa), for example, sometimes find themselves caught in a trap. ' Finally, when individuals "choose" to be trafficked as a result of economic, political, or family pressures at home, the authors argue that this does not negate the fact that their human rights are being violated.

Finally, we insist upon the importance of distinguishing between human smuggling and the traffic of human beings across international borders. Smuggling always entails illegal entry into a country, while trafficked individuals may enter with legal documents. As well, people smuggled into a country are free upon their arrival, while trafficked individuals remain under the control of a third party, whether through the use of violence, threats of violence against their families, or other forms of coercion. ${ }^{8}$ As mentioned, for some international migrants, smuggling may be the only exit from their own countries and the single means to cross borders. Smuggling is at times the only pos- 
sible way to leave the country of origin (especially for refugees), while trafficking exploits individuals for the profit of third parties. Canadian government agencies tend to have mandates that deal exclusively with smuggling rather than trafficking per se.

\section{Methods}

To successfully perform this study, a three-stage qualitative analysis was carried out. The analysis of documents (research reports, departmental documents, and reports of groups concerned) gave a better understanding of the issue of trafficking in persons. On the basis of the documentary analysis, a guide for semi-structured interviews and a questionnaire were prepared to be used with a sampling of key informants representing the main federal departments and agencies concerned in the effort to combat trafficking. In total, seventeen face-to-face interviews were conducted, in English or French, between November 1999 and April 2000. The interviews were conducted at each informant's workplace and lasted from one and one-half to three hours, depending on the interest shown by the interviewees and the amount of information they could provide. In some cases, follow-up interviews were conducted to supplement the information gathered. At the same time, four questionnaires were completed by key individuals living outside of the Ottawa and Montreal areas. Finally, Status of Women Canada held a round-table discussion on the topic of human trafficking, and the authors carefully transcribed and analyzed participants' presentations and discussions.

\section{Trafficking in the Context of Globalization}

Among the factors that explain the scale of human trafficking are economic globalization, the impact of structural adjustment policies on the feminization of poverty, the lack of laws or non-enforcement of those in effect, ${ }^{9}$ armed conflict, and even the complicity of some governments, particularly in economically poor countries, with organized crime. In addition, communications technologies are speeding the expansion of sex tourism, to the point of turning some developing countries into "body fairs."

\section{International Trade and Growing North-South Inequality}

The phenomenon of human trafficking cannot be separated from the expansion of economic globalization and growing North-South inequality. Informants for this project described many situations that illustrate this dynamic. Human trafficking is essentially a question of supply and demand of labour on a global level, and a source of wealth. A focus on agribusiness and economic development driven by the multinationals in the Third World has created disenfranchisement that forces many to look outside their home countries for economic opportunities.

Whether we are discussing trafficked farm, domestic, factory, or sex workers in Canada, we are confronting the fact that more profit can be made by paying less than is acceptable to Canadian citizens but is enough to entice individuals living in poverty in economically underdeveloped nations. Conditions are so poor, however, that traffickers must intimidate, threaten, or use violence against their victims in order to ensure their compliance. At the same time, many countries, such as the Philippines and El Salvador, have come to rely on the in-flow of foreign funds from its workers abroad. Developing nations implement programs such as the Philippine Labour Export Program, pushing their citizens to undertake sometimes dangerous and precarious work in order to obtain foreign currency to pay crushing international debts.

In the case of the international trafficking of children for adoption or women and children for the sex trade, we must confront the phenomenon of the commodification of human beings. ${ }^{11}$

\section{Transnational Organized Crime}

The role of well-organized transnational crime syndicates in human trafficking is growing. ${ }^{12}$ Data from the International Organization for Migration (IOM) suggest that the smuggling of migrants has created a black market for smugglers' services with an annual global monetary value of US\$7 billion. Organized crime involvement takes three principal forms: (1) smuggling itself, (2) human trafficking, and (3) smuggling or trafficking with the aim of facilitating other criminal activities (drug trafficking, theft, fraud). ${ }^{13}$ In Canada, a study of the impact of organized crime estimated that between 8000 and 16,00o people enter the country each year with the help of smugglers. ${ }^{14}$ According to Porteous, the majority of those smuggled subsequently apply for refugee status, and a large proportion can be assumed to be successful in their claims. The data to determine the proportion of those smuggled into Canada who are also trafficked do not exist.

\section{International "Irregular" Migration to Canada}

According to the un Centre for International Crime Prevention, throughout the world 4 million persons are trafficked each year. ${ }^{15}$ As stressed by Wichterich, this modern form of slavery has assumed vast proportions, but it is not a recent invention. As early as the 1960s, the global trade in 
women was recruiting victims from Southeast Asia (mainly Thailand, Malaysia, and the Philippines), with a second wave of women trafficked from Africa (Kenya, Ghana, Nigeria, and Zaire) in the 1970s. Trafficking from Latin America (Colombia, Venezuela, Ecuador, Panama, and the Dominican Republic) soon followed. Recently, the trade has spread to the People's Republic of China, the Mekong region, and East European countries, with Ukraine becoming the main global source for trafficking in girls and women. ${ }^{16}$ The United States Agency for International Development (USAID) statistics from 1998 show that, during the 1990s, some 400,000 Ukrainian women were recruited for trafficking to North America, Western Europe, and Israel. ${ }^{17}$ In the United States, where Asian prostitutes may be sold for up to Us $\$ 20,000$ each, Asian organized crime groups are said to control around 70 per cent of the sex industry. ${ }^{18}$ It is notable that the sources of trafficking often correspond with areas facing war or serious economic crisis-the usual sources of refugees.

\section{Estimated Incidence and Form of Trafficking in Canada}

Interview participants described many Canadian examples of trafficking. Women are trafficked for prostitution, thinking they are coming here for legitimate work under the Immigration Act as exotic dancers or as masseuses. Children are trafficked for illegal adoption, and men are trafficked to work in slavery-like conditions in factories, agrifood or agricultural settings. Other forms of trafficking include the cases of domestic workers or mail-order brides who are deprived of their freedom upon arrival in Canada, or have their passports taken away and their lives controlled by threats against themselves or their families. The fact remains, however, that with the current state of knowledge, it is not always easy to distinguish migrant smuggling from trafficking in persons, as defined by the newly adopted un protocol.

The problem of trafficking never shows up directly in the context of work performed by study participants in the field. Of the 12,00o refugees who claimed status upon landing in Canada in 1999 (representing 48 per cent of total refugees) ${ }^{19}$ however, it can be safely assumed that some of them were smuggled and/or trafficked into Canada. Instead, trafficking is revealed indirectly through operations targeting organized crime, such as goods smuggling, usury, fraud, and illegal gambling. The Montreal Police (sPcum) Intelligence Division, for example, has been able to identify trafficking cases during raids on unlicensed bars, massage parlours, or beauty salons. Another chance discovery occurred in Vancouver, where immigration officers found that some Malaysian women seeking entry had the proper visas but nothing but lingerie in their luggage!

Questioning at border posts, victims' "confessions," and the anonymous testimony of family witnesses are the most common means for detecting traffickers and their victims. However, the key element in operations to locate traffickers and their victims is a relationship of trust with informants unofficially employed by the RCMP's investigative service. The ethnic communities to which victims or traffickers belong are excellent sources for contacts because they are often the first to suspect trafficking cases in their midst. Examples of this type of partnership are investigations conducted in collaboration with the Toronto Police Service's Combined Forces Asian Investigative Unit (CFAIU), which combats organized crime in the Asian community. Through this type of unofficial cooperation, RCMP investigation heads were able to carry out Project Orphan in Toronto, making it possible to dismantle a network trafficking Malaysian women for prostitution. Once located, the women were repatriated, however, while the traffickers were handed over to the RCMP.

\section{Profile of Traffickers}

It is impossible to sketch a physical or even psychological profile of traffickers on the basis of information from intelligence databases of Citizenship and Immigration Canada (CIC), or from the RCMP. The information collected in our interviews and through our questionnaires was scarcely more revealing. For example, according to some accounts, the traffickers involved in facilitating border crossings are usually middle-aged Canadian men of foreign origin. However, no special feature seems to distinguish them: "They are like ordinary citizens," noted one informant. Incidentally, as smugglers continually change their smuggling routes to escape the vigilance of customs inspectors, it is no easier to detect their smuggling "system."

\section{Profile of Victims}

The information known about trafficking victims (men, women, and children) is also fragmentary and even confidential. Only the characteristics of apprehended illegal migrants are documented in Canada at the moment; illegal migrants, however, are not necessarily smuggled or trafficked. In this regard, CIC and the RCMP by and large have enough information to trace the country of origin, sex, age, and ethnic origin of illegal migrants. In addition, according to study participants, most illegal migrants are poor, disadvantaged young men (aged twenty-one to twenty- 
five), while occasionally there are young mothers who have left their children in their country of origin. Nevertheless, for political or religious reasons (in Iran, for example), some well-to-do people also seek to migrate illegally by turning to the services of a smuggler.

At present, it seems that the favoured targets of smugglers for exploitation are girls and young women aged sixteen to twenty-two, but little or no information about them has been collected in Canada. According to CIC, smugglers usually meet potential victims in hotels and prepare them to answer the questions of immigration officers. If a victim is refused entry, she is sometimes motivated to speak out. When victims can't stand it any longer, they contact cIc because they have nothing to lose.

\section{What Causes Victims to Leave Their Home?}

Apart from dreaming the "American dream" fed by the misleading pictures painted of an enticing future, most study participants thought that what prompts "potential" victims (and illegal migrants in general) to leave their country is structural conditions (socio-economic and political) found in some regions of the world. According to participants, illegal movements are directly related to labour market shifts—seasonal or irregular. The socio-political and economic characteristics of countries of origin would thus explain why people head for Canada. Armed conflict and oppressive governments also play a role.

Government complicity in some developing countries hardly eases the task of immigration officers. As one study participant noted, in the small Caribbean island of Dominica, citizenship may be purchased for a payment of between CAN $\$ 10,000$ and CAN $\$ 20,000$. Until very recently Dominica citizens needed no visa to enter Canada, and twenty Chinese people used this opportunity to gain entry. When this strategy was discovered, these Dominica "citizens" were repatriated to Dominica, and Canada now requires citizens of the island to have a visitor's visa. The problem, however, exists elsewhere, notably in some islands of the Pacific where authorities see this as a way of quickly filling their coffers.

\section{Routes, Modes of Transportation, and Destinations in Canada}

Other than the information acquired on routes and modes of transportation used by illegal migrants, no informant could give details about how trafficking victims enter Canada. cIc did, however, remark that the modes of transportation from the United States were bus or rental car.
Smugglers are said to keep the papers of victims, who enter the country first and are joined afterwards by the smugglers.

Once they have arrived in Canada, it is believed by some of the informants that most trafficked individuals are forced to work within their own ethnic communities in large cities (especially the Chinese, Latin American, and Caribbean communities). Toronto is thought to lead (with 46 per cent of cases), followed by Vancouver and Montreal. According to the SPCUM, trafficking in human beings has reached the saturation point in New York City and now is focusing on Canadian border cities.

\section{Payments Required}

According to RCMP information, each freighter illegally transporting migrants earns its owner approximately $\$ 1.5$ million in profits. As for payments required by smugglers or traffickers, study participants believe that these range from $\$ 15,000$ to $\$ 70,000$, depending on whether an individual or family is involved. Trafficking victims must continue paying their debts to traffickers for years, at interest rates that are often high and subject to change. Further, victims are often subjected to intimidation and extortion to make them pay their debt. In this situation, victims find it difficult to break out of the vicious circle. A telling example is that of some Asian men and women whose cultures hold that any debt incurred must be paid as a matter of honour. To succeed in paying back the debt, these people become still more vulnerable to exploitation by the traffickers, who incite them to perform criminal acts (drug payments, protection money, etc.). When victims do not pay up, their families are easy prey for these criminal organizations.

\section{Living and Working Conditions in Canada}

The exploitation of trafficking victims generally occurs after entry to Canada. Traffickers recover their papers (passport or employment authorization) and keep victims in their debt as long as they wish. Trapped in this way, these people live with the fear of being arrested by the police. The result is a cycle of threats and abuse of all kinds: working for less than minimum wage, forced debt, and violence. They are exploited in sweatshops (in the textile and agrifood industries), restaurants, the sex trade (exotic dancing, prostitution), and domestic work (household help), or else are involved in illegal activities, such as counterfeiting, stolen credit cards, and drug trafficking.

In Vancouver, for example, we were told about farm workers living in slavery-like conditions. Sweatshops have 
been identified in abandoned buildings on Spadina Avenue in Toronto and Casgrain Street in Montreal. The people working in these establishments (the majority of whom are women) go unnoticed most of the time. They are forced to work long hours for low pay, with their illegal status making their situation precarious. After acquiring some experience and skill in their field, in principle these individuals should receive a promotion. Instead they are forced to do different work and repeatedly to learn how to do a new job.

The Montreal Police estimate that, in Toronto and Montreal, there are 10,000 to 12,000 Sri Lankan and Cambodian women who have been forced into marriage in order to gain entry to Canada. Further, over the last three years, some women from the Philippines who came to Montreal to work as domestic workers are said to be paid at the rate of $\$ 10$ a week, while their employers take away their work visas and travel documents.

Often, trafficking in women and children leads to sex work. CIC gives the example of women who, thinking they were coming to Canada to work as hair stylists or beauticians, were finally forced to become erotic dancers in nightclubs. When they agreed to dance at a customer's table they would receive an extra $\$ 10$, but the money was later taken from them by the bar owner. In addition, the women could not go out alone and, in case of sickness or menstruation, their pay was docked.

Last, Health Canada should be worried about the direct negative impact of poverty, stress, and violence on the health of trafficking victims. Unfortunately, no concrete steps have yet been taken to address the health needs of this vulnerable population. This situation is striking since, when it comes to health, Canada has an enviable international reputation. ${ }^{20}$ Of course, when victims are discovered, the RCMP refers them to other bodies such as CIC, the local police, social services, municipal and provincial health services, or action and awareness groups from ethnic communities that can offer them legal recourse. However, there is no federal aid program specifically designed for the benefit of trafficking victims.

\section{Critique of the Current Government Response to Human Trafficking in Canada}

With the exception of the Department of Foreign Affairs and International Trade (DFAIT), ${ }^{21}$ the departments and agencies contacted have no mandate that refers specifically to trafficking in persons, although they do acknowledge the need to address the problem. In Canada, the legal framework (which does not directly address the trafficking prob- lem) or social policy and humanitarian concerns determine government mandates.

\section{Bill c-31 and Trafficking}

Although Bill C-31 died with the election call last fall, the content of the bill reflects what is the general orientation of the government toward trafficking. It can be assumed that although this version of the bill did not pass, a similar version will be reintroduced in the coming years. The bill prohibits "organizing [illegal] entry into Canada," "trafficking in persons," and "disembarking persons at sea." As well, "possession of property obtained by certain offences" is also prohibited. The penalties for engaging in these acts are outlined, yet there are no provisions for the prevention of trafficking or the protection of its victims. ${ }^{22}$

Emphasis elsewhere in the bill is on restricting entrance to Canada and on criminalizing all involvement in smuggling. Advocates have already raised the difficulties this orientation poses to potential refugees. ${ }^{23}$ The criminalization of individuals who are smuggled (and possibly trafficked) into the country puts at risk each individual's right to claim refugee status. The automatic detention of smuggled individuals and their ineligibility to make a refugee claim ignores the fact that, for many refugees, smuggling is the only possible route into Canada. And perhaps most disturbing, the criminalization of all forms of illegal entry would make victims of trafficking even less likely to appeal for help than at present.

Overall, punitive legislation such as the defunct Bill c31 would fail to stop trafficking or protect its victims, would criminalize all involvement in smuggling (putting at risk legitimate refugees), and would violate the basic human rights standards of international human-rights conventions and formally recognized international legal norms. ${ }^{24}$ The implications of this type of legislation for refugees who must use these forms of migration are severe.

\section{Need for Specific Mandates on Trafficking}

Federal government policies and programs are intended to combat illegal entry into Canada, in accordance with one key objective of Canadian foreign policy: to ensure our security by protecting against international crime and uncontrolled migration. However, it is difficult to distinguish irregular movements (labour force immigration, brain drain, refugees and asylum seekers on various grounds including religion, colour, and ethnic origin) from other, illegal activities, such as trafficking in human beings, arms dealing, drug smuggling, or even terrorism; and the diffi- 
culty casts doubts on the efficacy of controls on migratory flows. If controls are ineffective and human rights are not safeguarded, do we not lose more by closing borders than we do by opening them?

Among the many factors facilitating the expansion of international criminal organizations and their control over illegal migration are the demographic and economic conditions in developing countries, the globalization of movements of goods and capital, and the aspiration to similar living conditions around the world. Neither border controls alone nor sustainable development strategies (in particular, managing and funding projects) can halt the trends. But these are the two policies championed by the federal government (as proposed in Bill C-31) to eliminate trafficking in persons.

Basically restrictive in concept, the first policy (border controls) results in the interception of illegal migrants, without offering a genuine solution to the problem of trafficking in persons. To strengthen immigration law and sentences for traffickers, what is needed first is the ability to put into operation the government's existing definition of trafficking. ${ }^{25}$ In light of our documentary analysis and interviews, however, there is no guarantee that the definition will be put into effect. Already, the difficulty that border posts experience in differentiating between illegal migrants, smugglers, traffickers, and victims has harmful effects; one is that people come to live in a country without putting down roots. ${ }^{26}$ In the long term, far from punishing traffickers, the situation instead strips immigrants and refugees of basic rights, since it leads to the creation of a new category of second-class citizens, who live in fear of being arrested and are thus vulnerable to abuses of all kinds.

The second policy of sustainable development is based on respect for basic rights and humanitarian principles, but it is powerless to deal with the rise of criminal organizations modelled on large conglomerates. For example, Metropolis notes the emergence, in corporate form, of transnational crime networks integrated horizontally and vertically. The horizontal integration can be seen in participation in related criminal activities (arms and drug smuggling), and in making use of transnational transportation and distribution networks. The vertical integration implies control of the entire organized crime network, from production of illegal documents in the phase before migrants' entry, to the exploitation or quasi-slavery to which they are subjected after arrival, in traditionally illegal sectors (the sex trade, drugs, and sweatshops).
It is therefore urgent to base the policies and practices of federal departments and agencies on an operational definition of trafficking in persons.

\section{Need to Operationalize the UN Proposed Definition of Trafficking}

With no criteria for identifying traffickers and their victims, asks the CCR with reason, how can the definition in the UN Protocol ensure protection of the victims? The information gathered in the course of this study has shown that some trafficking cases are detected through indirect operations or the experience acquired by officers in border posts. For example, doubts about the truthfulness of the stories told by female refugee claimants sometimes prompt customs inspectors to search their cars, in which they find clothing and documents belonging to the claimants. These actions set in motion a process that leads to identification of smugglers and potential victims.

The findings of our analysis indicate to us the importance of adding indicators to cIc's intelligence database with the aim of drawing up profiles of smugglers, traffickers, and their victims in Canada. However, would introducing more combinations of variables facilitate detection of traffickers and their potential victims? That question must undergo study.

\section{"Victims": A Problematic Concept}

Further, the concept of "victim" is ambiguous. Some study participants saw victims as people who enter a country using the services of smugglers or traffickers. Others saw the victim as the receiving country that offers a social system "exploited" by illegal migrants. This ambiguity highlights the importance of examining immigration policy not only from a legal but also from a humanitarian perspective. If the victims of trafficking are not necessarily the illegal migrants, different actions and responsibilities are called for on the part of government.

\section{Protection versus Criminalization of Trafficking Victims}

Despite the wording of its title ("to prevent, suppress and punish trafficking in persons"), the protocol seems to give little attention to the issue of prevention. ${ }^{27}$ Article 10 (the only one relating to prevention) is brief and extremely general. Much is said about the vulnerability of victims and the need to protect them, but little or no concrete action is being taken to do so in Canada. Some study participants 
feel that "victims" should be arrested on entering Canada. This, they, believe, would force the migrants to appear before hearings on their status and to become applicants for official status, which would better protect them from the clutches of their traffickers. In contrast, other participants regard arrest on entry as a violation of human rights. Moreover, Article 14 of the Universal Declaration of $\mathrm{Hu}-$ man Rights states that "Everyone has the right to seek and to enjoy in other countries asylum from persecution." ${ }^{28}$

Where action has been taken, it is in criminalizing trafficking in persons, and the adoption of a bill such as C-31 would continue this trend..$^{29}$ According to some study participants, criminalization has a twofold impact: it eliminates middlemen and thereby reduces one part of the criminal network, but it has an undesirable effect on victims, since traffickers are not about to take a loss, and simply force their victims to pay still-higher fees. Considerable efforts must therefore be made to identify the range of public responses that should be developed to combat the lucrative industry of trafficking in persons and to distinguish it from other forms of illegal migration.

While punitive measures against traffickers are undoubtedly required, they should be accompanied by actions that would promote national and international cooperation agreements. For this purpose, together with NGOS working in the area of trafficking in Canada, it would be valuable to establish procedures for monitoring potential victims. By participating, NGOs would provide a more reassuring link between victims and the government. Members of ethnic communities find it easier to trust NGOs than federal departments and agencies, which are often perceived as distant bureaucratic organizations. Further, it would be useful to set up an information network linking federal departments and agencies, NGOs, activists, journalists, and lawyers working on the trafficking issue. Drawing on the model of the work of CIDA's Asian partners, Canada could also organize awareness workshops for professionals and the media in order to help them better understand the various aspects of trafficking. Such an approach would call into question the logic of closing borders and would thereby deflect the hostility of media-fed public opinion about illegal migrants.

\section{Need for a Global, Unified Approach}

In summary, understanding the problem of trafficking in its entirety is all the harder because illegal entry is only the tip of the iceberg. As Wihtol de Wenden says, "The real challenge for countries of destination lies not in an endless program to combat movements of persons, but rather in learn- ing to 'live together' and in the search for solutions offering all people the freedom to remain in their home countries." ${ }^{\prime 0}$ This is why Canada should adopt a global perspective rather than an approach that is local or based on countries of destination or temporary transit. Trafficking includes three major space-time dimensions in a chronological order: (1) recruitment and exploitation in the country of origin; (2) migration (legal or illegal) from one country to another; and (3) exploitation in the country of destination. Accordingly, the problem of trafficking should be addressed by collective efforts involving promotion, detection, prevention, and training in countries of origin. These comprehensive efforts would include identification of victims and traffickers in their countries of origin, plus border surveillance, criminal investigation, and protection of victims in countries of destination.

\section{Conclusion}

In conclusion, we believe that the effort to combat trafficking will be slowed rather than aided by punitive legislation such as that proposed in the former Bill C-31. The blanket criminalization of refugees who must use smuggling to escape dangerous or oppressive situations or of individuals who are the victims of trafficking will not stop the demand for these activities and will further victimize people whom Canada professes to want to protect.

Instead, Canada needs a twofold approach: First, joint action is needed by all levels of government in Canada, working in collaboration with the NGOs concerned. The government should seek to uncover and prosecute those who smuggle or traffic human beings for profit, but those individuals who are the subjects of these "irregular movements" should be given the opportunity to apply for refugee status, obtain work visas, and/or apply for landed immigrant status.

Second, Canada and countries at risk should develop a joint strategy to eliminate the structural conditions that drive potential victims to look for an illegal way out of their predicament. The first step is to examine Canada's participation in international trade and diplomacy. Supporting strong labour standards, debt reduction, and fair trade on a global scale is essential to reducing the poverty that pushes many people to emigrate illegally. Also, consistency in insisting on the protection of human rights both at home and abroad would lessen the need for people to migrate and their exploitation upon arrival in Canada. Two final key points emerging from our research are the need to implement innovative awareness and action programs to discourage victims from leaving their country of origin, 
and the need to find effective means of targeting the heads of international crime organizations involved in trafficking.

\section{Acknowledgement}

The authors received funding for their preliminary study ${ }^{31}$ from the Status of Women Canada's Policy Research Fund. The opinions expressed in this article, however, are the sole responsibility of the authors.

\section{Notes}

1. The Trafficking in Human Beings Project is directed by representatives from the following federal departments and agencies: the Department of Foreign Affairs and International Trade (DFAIT), the Canadian International Development Agency (CIDA), Citizenship and Immigration Canada (CIC), Statistics Canada (sc), the Department of the Solicitor General of Canada (sGC), the Department of Justice, the Royal Canadian Mounted Police (RсмP), the Canadian Security Intelligence Service (CsIs), the Metropolis Network, the Secretariat of the Policy Research Initiative, and Status of Women Canada (swc). swc's Research Directorate chairs the project steering group and provides project management.

2. Earlier researchers had noted, "Information on trafficking... at the federal level in Canada is very limited." Consulting and Audit Canada, "Trafficking in Women: Inventory of Information Needs and Available Information" (Ottawa: Citizenship and Immigration Canada, Strategic Policy, Planning and Research, 2000), 1.

3. For example, in countries where war has collapsed the government (Afghanistan, Somalia) or with oppressive governments that restrict travel (Iran, China).

4. Canada has been reluctant to recognize threats that are not targeted at individuals (i.e., civil war, famine), that involve gender persecution, or are based on economic exploitation (often a result of globalization) as bases for refugee status. Immigration and Refugee Board of Canada, "Civilian Non-Combatants Fearing Persecution in Civil War Situations." Online: <http:// www.irb.gc.ca/legal/guidline/civilian/cw_a_e.stm > (date accessed: November 2000); Immigration and Refugee Board of Canada. "Women Refugee Claimants Fearing Gender-Related Persecution: UPDATE." Online: <http://www.irb.gc.ca/legal/ guidline/women/gd4_a_e.stm > (date accessed: 20 November 2000).

5. Ad Hoc Committee on the Elaboration of a Convention against Transnational Organized Crime, "Revised Draft Protocol to Prevent, Suppress and Punish Trafficking in Persons, Especially Women and Children: Supplementing the United Nations Convention against Transnational Organized Crime," Document No. A/AC.254/4/Add.3/Rev.7 (Vienna: United Nations, 2000), 6.

An important and deplorable exception in Canada has been the forced removal of First Nations children for adoption by white families, as well as Canadian children and women coerced into the sex trade.

6. International Organization for Migration. "Traffickers Make Money through Humanitarian Crises.” Geneva: IOM, 1999; Coa- lition to Abolish Slavery and Trafficking. "Fact Sheet on Trafficking of Women and Children." Online: <http://www .trafficked-women.org/fact.html $>$ (date accessed: 3 September 1999).

7. Philippine Women Centre of B.C., "Canada: The New Frontier for Filipino Mail-Order Brides" (Vancouver: Philippine Women Centre of B.C., 2000).

8. In cases where individuals are smuggled into the country, free upon arrival but nonetheless live in fear as the subject of serious threats, intimidation or violence by those who facilitated migration in order to secure repayment of exorbitant debts, we would consider this also to constitute trafficking. Whether freedom is physically or psychologically curtailed, trafficking contravenes migrants' human rights and dignity.

9. Tenth un Congress on the Prevention of Crime and the Treatment of Offenders, "New Global Treaty to Combat 'Sex Slavery' of Women and Girls," Document No. DPI/2098 (Vienna: UN Dept. of Public Information, 200o).

10. Donna M. Hughes, The Sex Industry and the Internet Industry: Partners in the Globalization of Sexual Exploitation (New Brunswick, NJ: International Symposium on Technology and Society, Rutgers University, 1999); Christa Wichterich, La femme mondialisée (Paris: Solin, Actes Sud, 1999).

11. Philippine Women Centre of B.C., 2000.

12. Coalition to Abolish Slavery and Trafficking, "Fact Sheet on Trafficking of Women and Children." Online: <http://www .trafficked-women.org/fact.html> (date accessed: 3 September 1999).

13. International Organization for Migration, "Traffickers Make Money through Humanitarian Crises" (Geneva: IOM, 1999).

14. Samuel D. Porteous, "Organised Crime Impact Study Highlights," Catalogue No. JS42-83/1998 (Ottawa: Public Works and Government Services Canada, 1998).

15. Centre for International Crime Prevention. "Global Programme against Trafficking in Human Beings: An Outline for Action." Vienna: un Office for Drug Control and Crime Prevention, 1999.

16. Catherine Wihtol de Wenden, Faut-il-ouvrir les frontières? (Paris: Presses de Sciences Politiques, La Bibliothèque du citoyen, 1999).

17. USAID, "An Integrated Strategy to Address the Trafficking of Ukrainian Women” (Kiev: USAID, 1998).

18. Tenth Un Congress on the Prevention of Crime and the Treatment of Offenders, "New Global Treaty to Combat 'Sex Slavery' of Women and Girls," Document No. DPI/2098 (Vienna: un Dept. of Public Information, 2000).

19. Citizenship and Immigration Canada, "Facts and Figures 1999: Immigration Overview" (Ottawa: Citizenship and Immigration Canada, 2000).

20. Federal/Provincial/Territorial Advisory Committee on Population Health, "Statistical Report on the Health of Canadians" (Ottawa: Health Canada, 1999).

21. The Department of Foreign Affairs and International Trade's foreign policy objectives involved it directly in the international negotiations to adopt the anti-trafficking protocol supplementing the UN Convention.

22. Immigration and Refugee Protection Act. Government of Canada. 
Vol. C-31, 2000.

23. Centre Justice et Foi, Le Groupe de travail sur les réfugiés, and the Canadian Council for Refugees, "Position Paper on Bill c31 and Refugees")Montreal: Centre Justice et Foi, 2000); CCPCYA, "Response of the Canadian Council of Provincial Child Advocates to Bill C-31 (Proposed Amendments to the Immigration Act)" (Montreal: CCPCYA, 2000).

24. Global Alliance against Traffic in Women/Foundation against Trafficking in Women/ International Human Rights Law Group, "Human Rights Standards for the Treatment of Trafficked Persons" (New York: Global Alliance against Traffic in Women, 1999).

25. GCON, "Global Challenges and Opportunities Network: Policy Research Initiative." Online: <http://policyresearch .schoolnet.ca/networks/global/global-e.htm $>$ (date accessed: 18 October 2000).

26. Of course, there are those who would prefer, if we are unable to bar irregular migrants completely from entry to the country, that they remain outside of mainstream society. Wihtol de Wenden, 1999.

27. Ad Hoc Committee on the Elaboration of a Convention against Transnational Organized Crime, 2000.

28. Universal Declaration of Human Rights, New York: United Nations, 1948.

29. CCPCYA, 2000.

30. Wihtol de Wenden, 1999.

31. Oxman-Martinez, Jacqueline, and Andrea Martinez, "Trafficking in Human Beings in Canada: Summary of Federal Government Practices and Policy Issues" (Ottawa: Status of Women Canada, 2000).

Jacqueline Oxman-Martinez holds a Ph.D. in sociology from Université de Montréal (1986) and is a research associate at the Centre for Applied Family Studies, an adjunct professor of the McGill University School of Social Work, and an associate professor at the Universite de Montréal. She is coordinator of Component IV of the Immigration and Metropolis Centre of Excellence, which features the domains of health, social services, public safety, and justice.

Andrea Martinez is director of the Institute of Women's Studies at the University of Ottawa, an assistant professor at the Department of Communication at the same university, and the North American coordinator of the InterAmerican Training Network on Women and Development. She holds a Ph.D. in sociology from Université de Montréal (1994) and is involved in research related to media violence as well as Aboriginal women, new technologies, and globalization.

Jill Hanley is a Ph.D. candidate in l'Université de Montréal and McGill University's joint program, working on issues of community organizing, community develop- ment, and globalization. She is also a board member and activist with two tenants rights organizations in immigrant neighbourhoods as well as the Immigrant Workers' Centre. 